\title{
Sib risk of neural tube defect: is prenatal diagnosis indicated in pregnancies following the birth of a hydrocephalic child?
}

\author{
TIRZA COHEN, ELLEN STERN, AND ADA ROSENMANN \\ From the Department of Human Genetics, Hadassah-Hebrew University Medical Center, Jerusalem, Israel $\overrightarrow{\vec{\omega}}$
}

SUMMARY Recurrence frequencies of central nervous system malformations in sibs of probands with anencephalus or spina bifida range between $1 \%$ and $7 \%$. The frequency of hydrocephalus amoig sibs of such probands is low $(0.21 \%)$ but, nevertheless, is increased 2 to 5 -fold when compared to general population frequencies. Anencephalus and spina bifida cystica were observed in $1.65 \%$ of sibs of children with hydrocephalus, a 2- to 8-fold increase over the population frequencies. These data indicate that some aetiological factors may be common to all three malformations. The risk figure of $1.65 \%$ for anencephalus and spina bifida in sibs born after the birth of a hydrocepha政 proband constitutes sufficient indication for prenatal diagnosis by alphafetoprotein determination the amniotic fluid.

An increased frequency of sibs with either anencephalus or spina bifida exists following the birth of a proband with either of these conditions. However, little has been published concerning hydrocephalus in sibs of children with anencephalus or spina bifida, and, conversely, the occurrence of the latter two malformations after the birth of a hydrocephalic proband (Tables 1, 2, 3). Mid-trimester alphafetoprotein levels of amniotic fluid at present serve as a prenatal indicator of 'open' malformations of the fetal central nervous system (CNS), that is, anencephalus and spina bifida cystica. Therefore, the risk to sibs of hydrocephalic children of having an open CNS malformation is of great practical importance.

\section{Methods}

Estimates of these risks have been obtained from pertinent data in published reports as summarised in Tables 1,2, and 3. These data represent the published surveys which include detailed information on sibs of probands with CNS malformations. Naturally the studies are not completely comparable since methods of authors differed. In these studies, when definitions were stated, the 'anencephalus' group was defined as those patients with and without spina bifida and also iniencephalus; the 'spina bifida' group as those patients with and without hydrocephalus and also encephalocele, but not occult Received for publication 1 June 1978 spina bifida; and the 'hydrocephalus' group as the patients with hydrocephalus apparent in the pewinatal period and without spina bifida. Stillbir were included by some authors. The populationn incidence of CNS malformations (Tables 1, 2, \%) sometimes refers only to anencephalus and spima bifida. Though Yen and MacMahon (1968) stated that their data included former data of MacMahon et al. (1953), both surveys were included, since the former contains detailed information on the hydfocephalic sibs of probands.

Affected sibs were not classified as being bourn before or after the birth of the proband, since sueh information was sometimes lacking. The $\chi^{2}$ test. of heterogeneity (Snedecor, 1956) was calculated on total number of healthy and affected sibs in each survey.

\section{Results}

Morbidity among sibs of probands with anencepharus and spina bifida is shown in Tables 1 and 2. TAe frequency of CNS malformations among sibs $\mathrm{CO}_{\mathrm{Cf}}$ children with anencephalus is 1 to $6 \%$ (Table 1) अ9ुd with spina bifida is 2 to $7 \%$ (Table 2 ). The occurrease of hydrocephalus in sibs of probands with eitfer CNS malformation is 0 to $0.8 \%$. However, since all authors included hydrocephalus as a CNS malformation, and some included it among 'ot her malformations', the frequency may be higher. The $\chi^{2}$ test of heterogeneity of healthy and affected sकुgs 
Table 1 Morbidity among sibs of anencephalic probands

\begin{tabular}{|c|c|c|c|c|c|c|c|c|c|}
\hline \multirow[t]{2}{*}{ Survey } & \multicolumn{2}{|c|}{ Population incidence } & \multirow{2}{*}{$\begin{array}{l}\text { No. of } \\
\text { probands }\end{array}$} & \multicolumn{4}{|c|}{ No. of affected sibs } & \multicolumn{2}{|c|}{$\%$ of affected sibs } \\
\hline & $\begin{array}{l}\text { CNS } \\
\text { malform- } \\
\text { ations }(\%)\end{array}$ & $\begin{array}{l}\text { Anen- } \\
\text { cephalus } \\
(\%)\end{array}$ & & Total $\dagger \dagger$ & $\begin{array}{l}\text { Anen- } \\
\text { cephalus }\end{array}$ & $\begin{array}{l}\text { Spina } \\
\text { bifida }\end{array}$ & $\begin{array}{l}\text { Hydro- } \\
\text { cephalus }\end{array}$ & Total & $\begin{array}{l}\text { Hydrocephalus } \\
\text { only }\end{array}$ \\
\hline $\begin{array}{l}\text { Böök and Rayner (1950), Lund } \\
\text { MacMahon et al. (1953), }\end{array}$ & - & 0.06 & 67 & $1 / 88$ & 0 & 1 & 0 & $1 \cdot 14$ & 0 \\
\hline Rhode Island & 0.54 & $0 \cdot 19$ & 162 & $6 / 119$ & 2 & 3 & 1 & $5 \cdot 04$ & 0.84 \\
\hline Frézal et al. (1964), Paris & - & 0.05 & 254 & $9 / 423$ & 5 & 3 & 1 & $2 \cdot 13$ & $0 \cdot 24$ \\
\hline Williamson (1965), Southampton & $0 \cdot 60$ & $0 \cdot 20$ & 27 & $2 / 41$ & 2 & 0 & $\mathbf{0}$ & $4 \cdot 88$ & 0 \\
\hline Carter et al. (1968), Wales & 0.81 & $0 \cdot 35$ & $\begin{array}{l}245 \\
116\end{array}$ & $\begin{array}{l}15 / 424 \\
15 / 284\end{array}$ & $\begin{array}{l}7 \\
9\end{array}$ & $\begin{array}{l}8 \\
5\end{array}$ & $\begin{array}{l}0 \\
1\end{array}$ & $\begin{array}{l}3 \cdot 54 \\
5 \cdot 28\end{array}$ & $\begin{array}{l}0 \\
0 \cdot 35\end{array}$ \\
\hline $\begin{array}{l}\text { Smithells et al. (1968), Liverpool } \\
\text { Yen and MacMahon (1968), }\end{array}$ & - & 一 & 598 & $44 / 887$ & 26 & 13 & 5 & $4 \cdot 96$ & 0.56 \\
\hline $\begin{array}{l}\text { Rhode Island } \\
\text { Czeizel and Révész (1970), }\end{array}$ & 一 & 一 & 452 & $26 / 573$ & 14 & 12 & $5 / 1263^{*}$ & $4 \cdot 54$ & 0.40 \\
\hline Budapest & $0 \cdot 37$ & $0 \cdot 11$ & 151 & $7 / 186$ & 3 & 4 & $1 / 579^{*}$ & $3 \cdot 76$ & $0 \cdot 17$ \\
\hline Richards et al. (1972), Glasgow & $0 \cdot 56$ & $0 \cdot 28$ & 146 & $26 / 454$ & 18 & 8 & 0 & $5 \cdot 73$ & 0 \\
\hline Carter and Evans (1973), London & $0 \cdot 30$ & $0 \cdot 14$ & 392 & $43 / 754$ & 24 & 17 & $2 \dagger$ & $5 \cdot 70$ & $0 \cdot 26$ \\
\hline
\end{tabular}

*, no. of hydrocephalics among sibs of probands with anencephalus or spina bifida;

$t$, listed in 'other malformations';

$\dagger \dagger, \chi^{2}$ test of heterogeneity between affected and non-affected sibs in 11 studies, $\chi^{2}=13 \cdot 76, \mathrm{df}=10, \mathrm{P}=0 \cdot 1855$.

is high for spina bifida (Table $2 ; \mathbf{P}=0.002$ ) indicating that the results of the morbidity surveys in sibs of spina bifida patients are not homogeneous. On the other hand, the results of sibs of probands with anencephalus (Table $1 ; P=0 \cdot 186$ ) and hydrocephalus (Table $3 ; \mathrm{P}=0.347$ ) are homogeneous. Sibs of children with hydrocephalus often have hydrocephalus ( 0 to $4 \%$ ), but also may have anencephalus or spina bifida ( 0 to $3 \%$ ) (Table 3 ). However, the possibility should be considered that some patients, both probands and sibs, diagnosed as hydrocephalics in fact had hydrocephalus secondary to spina bifida which was either not recognised or not recorded in the medical notes. Subgroups within Table 3, that is, sibs affected with anencephalus and/ or spina bifida among all sibs, and those affected with hydrocephalus among all sibs, do not deviate from homogeneity $(P=0 \cdot 370$ and $P=0 \cdot 404$, respectively).
The frequency of affected sibs for each of the three CNS malformations, as calculated from the above data (Table 4), shows that the highest risk to sibs is for the same malformation as observed in the proband: anencephalus $2.6 \%$, spina bifida $3.0 \%$, and hydrocephalus $1 \cdot 6 \%$. The frequency of hydrocephalus among sibs of probands with anencephalus or spina bifida $(21 / 9794)$ is $0.21 \%$. Though this figure is low, it is still two to five times greater than the population frequencies. The frequency of anencephalus and spina bifida among sibs of children with hydrocephalus $(16 / 1972)$ is $1.6 \%$, two to eight times the population frequencies.

\section{Conclusions}

These results lead to two conclusions:

(1) Common aetiological factors may exist in all

Table 2 Morbidity among sibs of probands with spina bifida

\begin{tabular}{|c|c|c|c|c|c|c|c|c|c|}
\hline \multirow[t]{2}{*}{ Survey } & \multicolumn{2}{|c|}{ Population incidence } & \multirow{2}{*}{$\begin{array}{l}\text { No. of } \\
\text { probands }\end{array}$} & \multicolumn{4}{|c|}{ No. of affected sibs } & \multicolumn{2}{|c|}{$\%$ of affected sibs } \\
\hline & $\begin{array}{l}\text { CNS } \\
\text { malform- } \\
\text { ations }(\%)\end{array}$ & $\begin{array}{l}\text { Spina bifida } \\
(\%)\end{array}$ & & Total $\dagger$ & $\begin{array}{l}\text { Anen- } \\
\text { cephalus }\end{array}$ & $\begin{array}{l}\text { Spina } \\
\text { bifida }\end{array}$ & $\begin{array}{l}\text { Hydro- } \\
\text { cephalus }\end{array}$ & Total & $\begin{array}{l}\text { Hydrocephalus } \\
\text { only }\end{array}$ \\
\hline \multicolumn{10}{|l|}{ MacMahon et al. (1953), } \\
\hline Rhode Island & $0 \cdot 54$ & $0 \cdot 25$ & 215 & $11 / 166$ & 5 & 6 & 0 & $6 \cdot 63$ & 0 \\
\hline Lorber (1965), Sheffield & 0.50 & - & 539 & $85 / 1256$ & 22 & 54 & 9 & $6 \cdot 77$ & 0.72 \\
\hline Williamson (1965), Southampton & 0.60 & $0 \cdot 32$ & 59 & $7 / 119$ & 1 & 6 & 0 & $5 \cdot 88$ & 0 \\
\hline & & & 276 & $35 / 518$ & 15 & 20 & 0 & $6 \cdot 76$ & 0 \\
\hline Carter et al. (1908), wales & 0.81 & 0.41 & 147 & $17 / 336$ & 5 & 12 & $\mathbf{0}$ & $5 \cdot 06$ & 0 \\
\hline $\begin{array}{l}\text { Smithells et al. (1968), Liverpool } \\
\text { Yen and MacMahon (1968), }\end{array}$ & - & - & 729 & $33 / 903$ & 20 & 11 & 2 & $3 \cdot 65$ & 0.22 \\
\hline $\begin{array}{l}\text { Rhode Island } \\
\text { Czeizel and Révész (1970), }\end{array}$ & - & 一 & 585 & $32 / 690$ & 14 & 18 & $5 / 1263^{*}$ & $4 \cdot 64$ & 0.40 \\
\hline Budapest & $0 \cdot 37$ & $0 \cdot 18$ & 292 & $9 / 393$ & 0 & 9 & $1 / 579 *$ & $2 \cdot 29$ & $0 \cdot 17$ \\
\hline Richards et al. (1972), Glasgow & $0 \cdot 56$ & $0 \cdot 28$ & 172 & $25 / 450$ & 6 & 19 & 0 & $5 \cdot 56$ & 0 \\
\hline Carter and Evans (1973), London & $0 \cdot 30$ & $0 \cdot 15$ & 478 & $25 / 730$ & 12 & 13 & 0 & $3 \cdot 42$ & 0 \\
\hline
\end{tabular}

*, no of hydrocephalics among sibs of probands with anencephalus or spina bifida;

$t, \chi^{2}$ test of heterogeneity between affected and non-affected sibs in 10 studies, $\chi^{2}=26 \cdot 47, \mathrm{df}=9, P=0 \cdot 0022$. 
Table 3 Morbidity among sibs of hydrocephalic probands

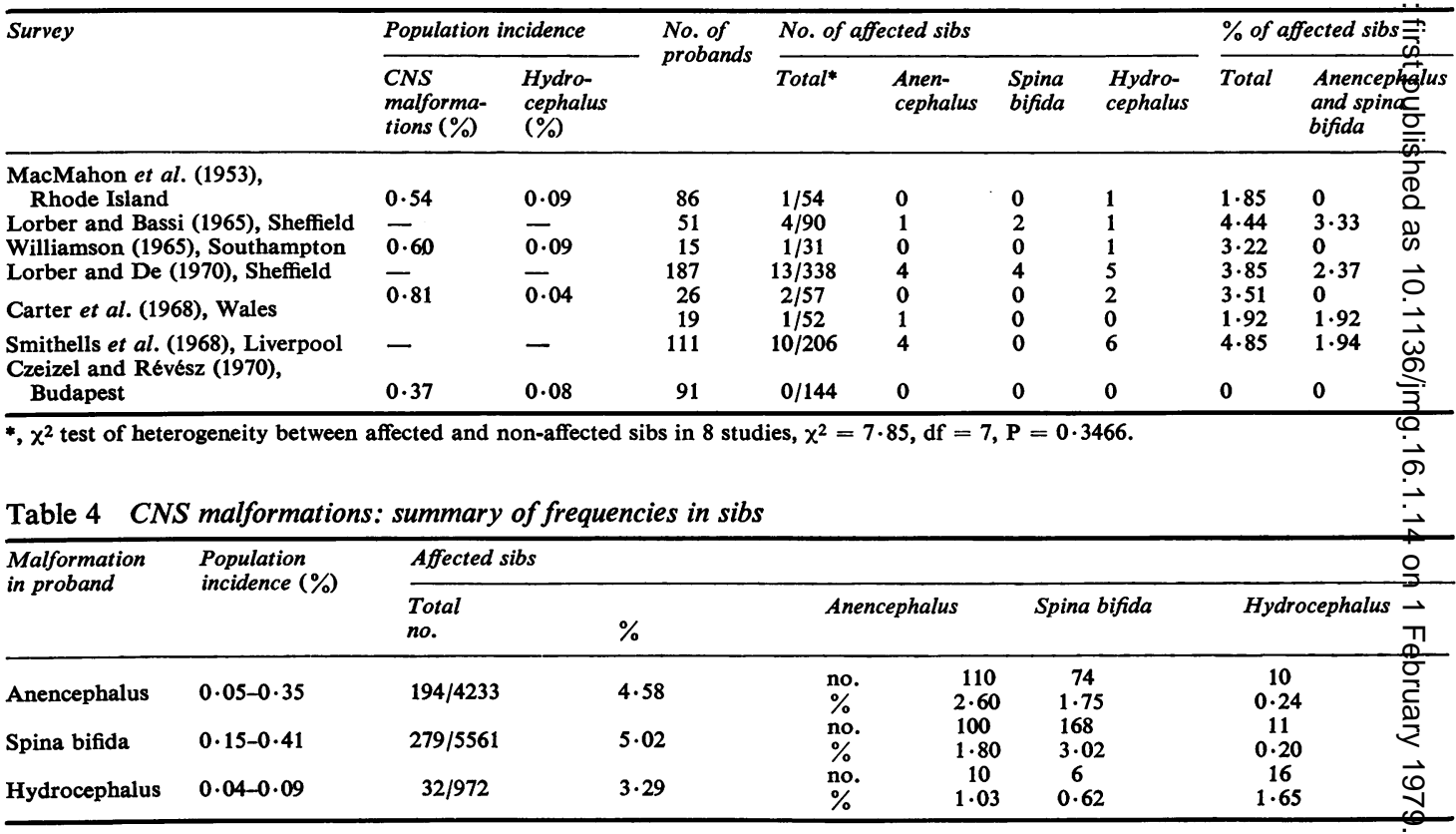

three CNS malformations, as indicated by the high frequency of spina bifida among sibs of anencephalics and vice versa, and by the increased frequency of hydrocephalus among the sibs of probands with anencephalus and/or spina bifida and vice versa.

(2) For practical purposes, the results in Table 4 show that the frequency of anencephalus and spina bifida among 972 sibs of children with congenital hydrocephalus was $1.65 \%$. Since a risk figure of $1 \%$ is usually considered adequate to suggest prenatal diagnosis by amniocentesis, we propose that alphafetoprotein determination in amniotic fluid is indicated in mothers of children with hydrocephalus.

This study was supported in part by a grant from the Joint Research Fund of the Hebrew University and Hadassah.

\section{References}

Böök, J. A., and Rayner, S. (1950). A clinical and genetical study of anencephaly. American Journal of Human Genetics, 2, 61-84.

Carter, C. O., David, P. A., and Laurence, K. M. (1968). A family study of major central nervous system malformations in South Wales. Journal of Medical Genetics, 5, 81-106.

Carter, C. O., and Evans, K. (1973). Spina bifida and anencephalus in Greater London. Journal of Medical Genetics, 10, 209-221.
Czeizel, A., and Révész, C. (1970). Major malformations of the central nervous system in Hungary. British Journal of Preventive and Social Medicine, 24, 205-222.

Frézal, J., Kelly, J., Guillemot, M. L., and Lamy, M. (1\%્ષ4). Anencephaly in France. American Journal of Human Genetics, 16, 336-350.

Lorber, J. (1965). The family history of spina bifida cys Pediatrics, 35, 589-595.

Lorber, J., and Bassi, U. (1965). The aetiology of neoratal hydrocephalus. Developmental Medicine and Child Nêtro$\log y, 7,289-294$.

Lorber, J., and De, N. C. (1970). Family history of congegital hydrocephalus. Developmental Medicine and Child Neurology, 12, Suppl. 22, 94-100.

MacMahon, B., Pugh, T. F., and Ingalls, T. H. (19;3). Anencephalus, spina bifida and hydrocephalus. Brôsh Journal of Preventive and Social Medicine, 7, 211-219.

Richards, I. D. G., McIntosh, H. T., and Sweenie, S. (1982). Genetic study of anencephaly and spina bifida in Glasgow. Developmental Medicine and Child Neurology, 14, 626-

Smithells, R. W., D'Arcy, E. E., and McAllister, E. F. (1\%8). Outcome of pregnancies before and after birth of infants with nervous system malformations. Developmental Medicine and Child Neurology, Suppl. 15, 6-10.

Snedecor, G. W. (1956). Statistical Methods. Iowa College Press, Ames, Iowa.

Williamson, E. M. (1965). Incidence and family aggregation of major congenital malformations of central nervous system. Journal of Medical Genetics, 2, 161-172.

Yen, S., and MacMahon, B. (1968). Genetics of anencep and spina bifida. Lancet, 2, 623-626.

Requests for reprints to Dr Tirza Cohen, Depẹrtment of Human Genetics, Hadassah University Hospital, Jerusalem, Israel. 